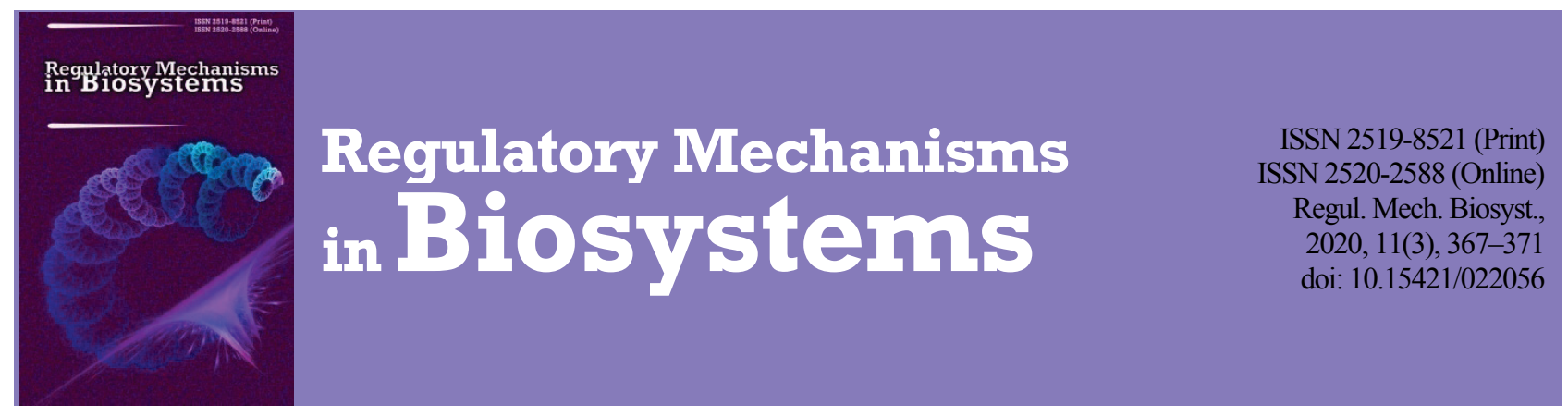

\title{
The effect of the combined action of nickel and copper ions on the initial stages of ontogenesis of Alisma plantago-aquatica
}

\author{
E. G. Krylova, E. V. Garin \\ Papanin Institute for Biology of Inland Water Russian Academy of Sciences, Borok, Russia
}

Article info

Received 29.05.2020 Received in revised form 10.07.2020

Accepted 11.07.2020

Krylova, E. G., \& Garin, E. V. (2020). The effect of the combined action of nickel and copper ions on the initial stages of ontogenesis of Alisma plantago-aquatica. Regulatory Mechanisms in Biosystems, 11(3), 367-371. doi:10.15421/022056

Papanin Institute for Biology

Surface water pollution has a complex multicomponent nature, due to a combination of various heavy metals that have a synergistic or antagonistic effect on various physiological parameters. Under model conditions, the combined effect of several heavy metals on aquatic plants was studied in terms of their toxicity, taking into account the nature of the interaction. In laboratory conditions, we studied the effect of nickel and copper ions and their mixtures in different concentrations on seed germination, growth and development of seedlings of the coastal-aquatic plant Alisma plantago-aquatica L. At the end of the experiment, seed germination, inhibition coefficient, morphometric indicators of seedlings and tolerance index were determined. Alisma seeds are highly resistant to nickel and copper chlorides and their mixtures. The toxicity limit for seed germination at $1-500 \mathrm{mg} / \mathrm{L}$ was not detected, although the inhibition coefficient in all variants of the experiment increased. A greater toxic effect of copper ions was noted compared to nickel ions. With the joint action of two metals on seed germination, a change in the nature of the effect from an independent action at low concentrations to antagonism at high concentrations was revealed. The growth and development of seedlings was observed at $1-100$ $\mathrm{mg} / \mathrm{L}$. The main inhibitory effect of heavy metals was on the length of the main root, the first true leaf, and the number of adventitious roots. Necrosis of the root system and hypocotyl, a weakening of the differentiation of the site of transition of the hypocotyl to the cotyledon, a change in the shape of the cotyledon, the colour intensity and turgor of the cotyledon and leaves were noted. The tolerance index showed that resistance at a level above $50 \%$ to the action of nickel, copper and their mixture was maintained at $1 \mathrm{mg} / \mathrm{L}$. In the case of the development of hypocotyl and cotyledon, copper was more toxic than nickel; nickel had a greater inhibitory effect on leaves. Under the action of the heavy metal mixture on the growth and development of seedlings, the independent action at low concentrations changed to antagonistic at high concentrations, which is probably due to competition in a number of indicators between nickel and copper.

Keywords: nickel and copper chlorides; seed germination; inhibition coefficient; morphometric indicators; tolerance index.

\section{Introduction}

Due to the increase in environmental pollution, studies of the absorption and primary incorporation of heavy metals into plant metabolism are becoming more and more popular. In small quantities, many of the heavy metals are necessary for normal plant life, for example, copper, zinc, manganese and nickel are part of various biological complexes. However, in high concentrations, they inhibit growth and affect viability, disrupting the physiological and biochemical processes in the cells (Devi \& Prasad, 2005; Hu et al., 2009).

Since plants are important components of aquatic ecosystems, and all anthropogenic influences enter the hydrosphere through processes associated with the water cycle, identifying the resistance of higher aquatic plants to heavy metal pollution is a priority in modern biology (Devi \& Prasad, 2005; Zaripova \& Stefanovich, 2008; Maleva et al., 2012). The ability of higher water plants to accumulate heavy metals in significant quantities, forming non-toxic complexes, opens up wide prospects for their use in monitoring and phytoremediation (Malec et al., 2009; Maleva et al., 2009).

Recently, many works on the influence of individual ions have appeared in the literature, but the combined effect of two or more metals has not been studied sufficiently (Brygadyrenko \& Ivanyshyn, 2015; Marenkov et al., 2018). In nature, metal ions are rarely found in isolation from each other, and surface water pollution is complex multicomponent, due to a combination of various heavy metals that have a synergistic or antagonistic effect on various physiological parameters. Therefore, under model conditions, the combined effect of several heavy metals on aquatic plants should be investigated not only in terms of their toxicity, but also taking into account the nature of the interaction. Knowledge of the physiological and biochemical mechanisms of plant resistance to the combined action of heavy metal ions will expand the understanding of the plasticity of metabolic processes and the limits of sensitivity to them (Maleva et al., 2012). The purpose of this study is to determine the resistance of the initial stages of ontogenesis (seed germination, growth and development of seedlings) of Alisma plantago-aquatica L. to the combined action of nickel and copper ions.

\section{Materials and methods}

Seeds of A. plantago-aquatica were collected in periodically drying shallow water of the Chesnava River (Breitovsky District, Yaroslavl Region) in September 2019. Their germination was carried out according to the "International rules for determining the quality of seeds" (Leurda, 1969). For cold stratification, the seeds were placed in distilled water at a temperature of $+4 \ldots+8{ }^{\circ} \mathrm{C}$ for 3 months. Then in batches of 50 pcs they were germinated on a Petri dish in a luminostat at a temperature of 20 $25^{\circ} \mathrm{C}$ on filter paper moistened with solutions of salts of $\mathrm{NiCl}_{2} \cdot 6 \mathrm{H}_{2} \mathrm{O}$ and $\mathrm{CuCl}_{2} \cdot 2 \mathrm{H}_{2} \mathrm{O}$ (chemically pure) in a volume of $15 \mathrm{~mL}$ each at concentrations of $1,10,25,50,100,250$ and $500 \mathrm{mg} / \mathrm{L}, \mathrm{pH}$ 6.8-7.2 (the graphs show white and grey bars, respectively). High concentrations were used to identify the toxic limit of heavy metals (concentrations above which the seeds did not germinate). Mixtures of these salts were also taken in a 1:1 ratio at the same concentrations $(7.5 \mathrm{~mL}$ of each salt solution per Petri 
dish) (in the graphs $\mathrm{NiCl}_{2} \cdot 6 \mathrm{H}_{2} \mathrm{O}+\mathrm{CuCl}_{2} \cdot 2 \mathrm{H}_{2} \mathrm{O}$ - black bar). Distilled water was used as a control. The experiments were performed in triplicate at an illumination of $3200 \lambda$ and a photoperiod of $9 / 15$ (light:darkness). The experiment lasted 14 days. The time (day) from the beginning of the experiment to the rooting of the seed cover (lag time), the time (day) during which the seeds sprouted (germination period) and the number of germinated seeds (\%) at the end of the experiment (germination) were determined (Shipley \& Parent, 1991; Nikolaeva et al., 1999). At the end of the experiment, randomly taking 20 seedlings from each variant where the seeds sprouted, the length of the main root, hypocotyl, cotyledon, first true leaf were measured and the number of subordinate roots was counted. The inhibition coefficient $\left(\mathrm{K}_{\text {ing }}\right)$ was also calculated by the ratio of the number of germinated seeds in the control $\left(\mathrm{N}_{\mathrm{k}}\right)$ to the number of germinated seeds in the experiment $\left(\mathrm{N}_{\mathrm{o}}\right)$ : $\mathrm{K}_{\mathrm{ing}}=\mathrm{N}_{\mathrm{k}} / \mathrm{N}_{\mathrm{o}}$ and the tolerance index (TI) or "root test" according to the formula: $\mathrm{TI}=\mathrm{L}_{\text {experience }} / \mathrm{L}_{\text {control }} \times 100 \%$, where: $\mathrm{TI}$ - index of tolerance (\%); $\mathrm{L}_{\text {experience }}-$ the length of the roots of seedlings grown under the influence of heavy metals $(\mathrm{mm}) ; \mathrm{L}_{\text {control }}$ is the root length of the control seedlings (mm) (Willkins, 1978; Samantarey et al., 1997; Chesnokova et al., 2016). Statistical analysis of the data was carried out using the Statistica package (StatSoft Inc., USA). Data were presented as means and their standard deviations $(x \pm \mathrm{SD})$. One-way analysis of variance was used, differences between the mean values were calculated using the Tukey test adjusted for Bonferroni, which are considered significant at $\mathrm{P}<0.05$.

\section{Results}

The effect of salts of copper, nickel and their mixtures on seed germination. Seeds in the experiment germinated simultaneously, the lag time was similar to the control values (2-3 days). When compared with the control variant (5 days), an increase in the germination period to 7-9 days was observed under the action of each heavy metal separately (nickel and copper concentrations of 250 and $500 \mathrm{mg} / \mathrm{L}$ ), as well as with their combined effect (concentration of $50-500 \mathrm{mg} / \mathrm{L}$ ).

In all variants of the experiment, the germination process was inhibited. Germination under the influence of nickel ions significantly decreased at 25,250 , and $500 \mathrm{mg} / \mathrm{L}$; copper ions significantly changed it at concentrations of 10-500 mg/L (Fig. 1, Table 1). The combined action of ions caused significant differences between this indicator and the control only at 250 and $500 \mathrm{mg} / \mathrm{L}$.

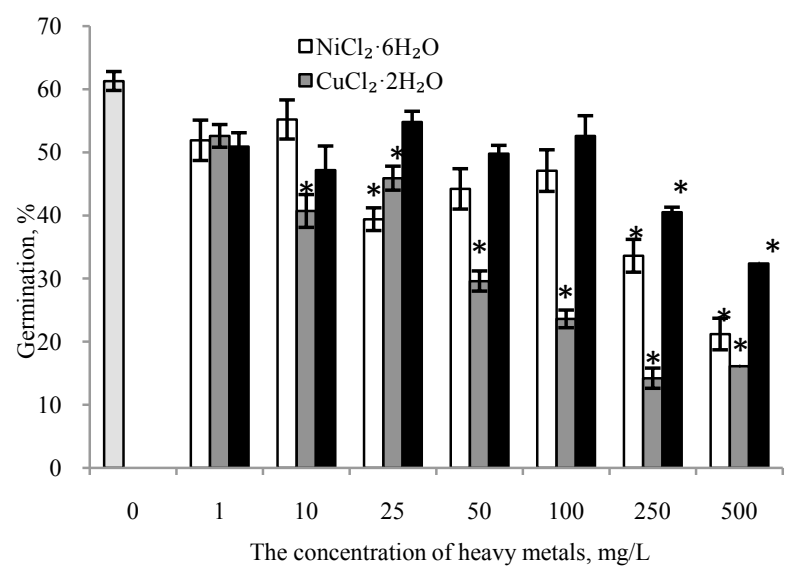

Fig. 1. The effect of heavy metal ions on seed germination: $\mathrm{x} \pm \mathrm{SD}, \mathrm{n}=3 ; *$ - significant differences compared with control

For nickel chloride, a wave-like decrease in the percentage of germinated seeds was noted, significant after a concentration of $10 \mathrm{mg} / \mathrm{L}$. The differences are statistically significant at $\mathrm{P}<0.05$ for variants 25 and $50 \mathrm{mg} / \mathrm{L}$ with variants 1 and $10 \mathrm{mg} / \mathrm{L}$, for variants 250 and $500 \mathrm{mg} / \mathrm{L}$ with all the others. Copper chloride was more toxic to seed germination than nickel chloride, and after a concentration of $25 \mathrm{mg} / \mathrm{L}$, a steady decrease in seed germination was noted. The differences are statistically significant for variants 10 and $25 \mathrm{mg} / \mathrm{L}$ with variant $1 \mathrm{mg} / \mathrm{L}$, for variant $50 \mathrm{mg} / \mathrm{L}$ with variant $1-25 \mathrm{mg} / \mathrm{L}$, for variant $100 \mathrm{mg} / \mathrm{L}$ with variant $1-50 \mathrm{mg} / \mathrm{L}$, for 250 and $500 \mathrm{mg} / \mathrm{L}-$ from $1-100 \mathrm{mg} / \mathrm{L}$. The combined effect of these salts was accompanied by a wave-like change in the germination rate, as in nickel, and at $25 \mathrm{mg} / \mathrm{L}$ and higher this indicator turned out to be greater than under the action of each salt separately. The differences are statistically significant for the $10 \mathrm{mg} / \mathrm{L}$ variant with the $1 \mathrm{mg} / \mathrm{L}$ variant, for the $50 \mathrm{mg} / \mathrm{L}$ variant with the 1 and $25 \mathrm{mg} / \mathrm{L}$ variants, for the $100 \mathrm{mg} / \mathrm{L}$ variant with the $50 \mathrm{mg} / \mathrm{L}$ variant, for the 250 and 500 variants $\mathrm{mg} / \mathrm{L}$ - with all the others. The inhibition coefficient in all variants of the experiment increased slightly, more under the action of copper ions, and the toxicity limit of all the studied salts for seed germination was not found (Table 1).

\section{Table 1}

Change in the coefficient of inhibition of seed germination of A. plantago-aquatica in solutions of nickel salts, copper and their mixtures

\begin{tabular}{cccc}
\hline Heavy metal & \multicolumn{3}{c}{ Inhibition rate } \\
\cline { 2 - 4 } concentration, $\mathrm{mg} / \mathrm{L}$ & $\mathrm{Ni}^{2+}$ & $\mathrm{Cu}^{2+}$ & $\mathrm{Ni}^{2+}+\mathrm{Cu}^{2+}$ \\
\hline 1 & 1.2 & 1.2 & 1.2 \\
10 & 1.1 & 1.5 & 1.3 \\
25 & 1.6 & 1.3 & 1.1 \\
50 & 1.4 & 2.1 & 1.2 \\
100 & 1.3 & 2.6 & 1.2 \\
250 & 1.8 & 4.3 & 1.5 \\
500 & 2.9 & 3.8 & 1.9 \\
\hline
\end{tabular}

The effect of salts of copper, nickel and their mixture on the growth and development of seedlings. Under the action of the studied salts at concentrations of 1-100 $\mathrm{mg} / \mathrm{L}$, the growth and development of seedlings was observed. Moreover, a significant inhibitory effect was noted on the length of the main root, the first true leaf and the number of subordinate roots. The main root was absent as a result of the action of nickel and copper at concentrations above $50 \mathrm{mg} / \mathrm{L}$, and their combined action was above $100 \mathrm{mg} / \mathrm{L}$ (Fig. 2). A significant decrease in this indicator under the influence of nickel was noted already at $1 \mathrm{mg} / \mathrm{L}$, under the influence of copper and a mixture of metals $-10 \mathrm{mg} / \mathrm{L}$. Starting from a concentration of $25 \mathrm{mg} / \mathrm{L}$, the length of the main root as a result of the combined action of metals was significantly higher than under the action of each metal separately. Partial necrosis of both the main and adnexal roots was detected at $10 \mathrm{mg} / \mathrm{L}$ for both metals and their mixtures. Under the influence of a concentration of $25 \mathrm{mg} / \mathrm{L}$ of nickel and copper, complete root necrosis was recorded.

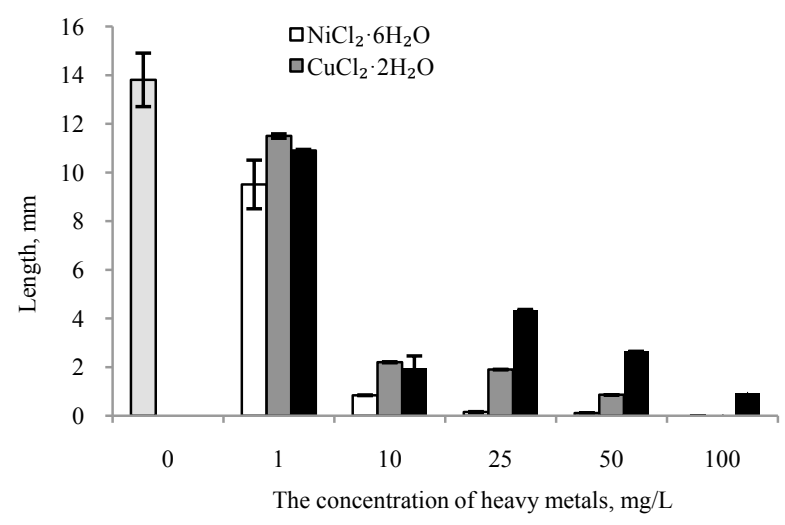

Fig. 2. The influence of heavy metal ions on the length of the main $\operatorname{root}(x \pm S D, n=20)$

A change in the index of tolerance to the action of heavy metals, determined by the length of the main root, confirmed what was said earlier (Table 2).

Table 2

Changes in the tolerance index of $A$. plantago-aquatica seedlings in solutions of nickel, copper salts and their mixtures

\begin{tabular}{cccc}
\hline Heavy metal & \multicolumn{3}{c}{ Tolerance index } \\
\cline { 2 - 4 } concentration, $\mathrm{mg} / \mathrm{L}$ & $\mathrm{Ni}^{2+}$ & $\mathrm{Cu}^{2+}$ & $\mathrm{Ni}^{2+}+\mathrm{Cu}^{2+}$ \\
\hline 1 & 68.9 & 83.3 & 78.9 \\
10 & 6.1 & 15.9 & 14.2 \\
25 & 1.1 & 13.8 & 31.4 \\
50 & 0.8 & 6.2 & 19.1 \\
100 & 0 & 0 & 6.6 \\
\hline
\end{tabular}


The adnexal roots were formed only at $1-25 \mathrm{mg} / \mathrm{L}$ of salts of nickel, copper, and their mixture. Their number significantly decreased at 10 and $25 \mathrm{mg} / \mathrm{L}$ of a mixture of heavy metals and at $25 \mathrm{mg} / \mathrm{L}$ of copper and nickel ions. Nickel in low concentrations stimulated the development of accessory roots (Fig. 3). Necrosis of the accessory roots was noted under the action of both metals and their mixtures at a concentration of $10 \mathrm{mg} / \mathrm{L}$.

The subcotyledonous knee (hypocotyl) is the most stable part of the seedling. Its presence is shown in all variants of the experiment at all concentrations of heavy metals. Under the influence of nickel concentrations of $10-50 \mathrm{mg} / \mathrm{L}$, the hypocotyl was $1.2-1.3$ times longer than the control values, at 25 and $50 \mathrm{mg} / \mathrm{L}$ of copper $-1.0-1.3$ times longer than the control value, and the effect of a mixture of salts at $25-100 \mathrm{mg} / \mathrm{L}$ was 1.2 1.4 times longer (Fig. 4). A significant decrease in hypocotyl was noted in the presence of nickel and copper at concentrations of 250 and $500 \mathrm{mg} / \mathrm{L}$. However, at $10 \mathrm{mg} / \mathrm{L}$, in all experimental variants, necrosis of the tip of the hypocotyl was already detected. An increase in the concentration of heavy metals led to increased necrosis and weakening of the differentiation of the site of transition of the hypocotyl to the cotyledon.

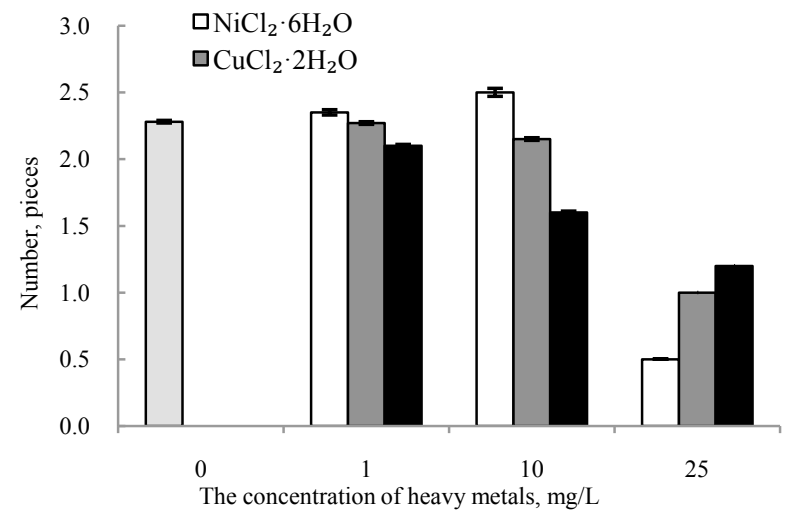

Fig. 3. The influence of heavy metal ions on the number of subordinate roots $(\mathrm{x} \pm \mathrm{SD}, \mathrm{n}=20)$

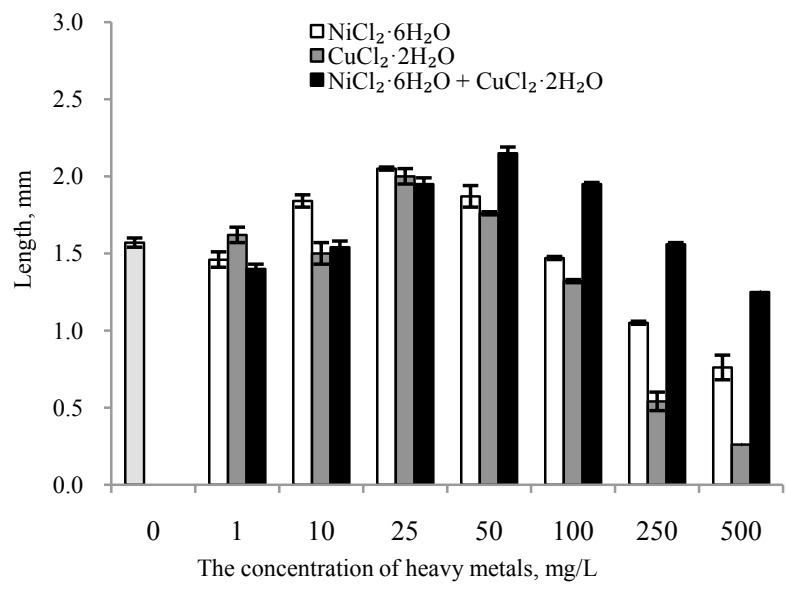

Fig. 4. The effect of heavy metal ions on the length of the hypocotyl $(\mathrm{x} \pm \mathrm{SD}, \mathrm{n}=20)$

The cotyledon significantly decreased starting from a concentration of $25 \mathrm{mg} / \mathrm{L}$ both in the case of the action of nickel and copper separately, and their mixture. It persisted even at the highest concentrations (Fig. 5). However, partial cotyledon necrosis and a change in their shape were noted already at $25 \mathrm{mg} / \mathrm{L}$. A further increase in the concentration of heavy metals increased necrosis and reduced the intensity of their colour.

Low concentrations of heavy metals $(1 \mathrm{mg} / \mathrm{L})$ and their mixtures contributed to the normal development of the first true leaf. An increase in concentration to $10 \mathrm{mg} / \mathrm{L}$ caused a significant decrease compared with the control of its length, which was accompanied by a change in colour intensity (Fig. 6). Nickel at concentrations of 25 and $50 \mathrm{mg} / \mathrm{L}$ completely inhibited the development of leaves, copper caused such changes at $50 \mathrm{mg} / \mathrm{L}$. Under the action of a mixture of metals in this concentration, the leaves developed, but their turgor and colour changed.

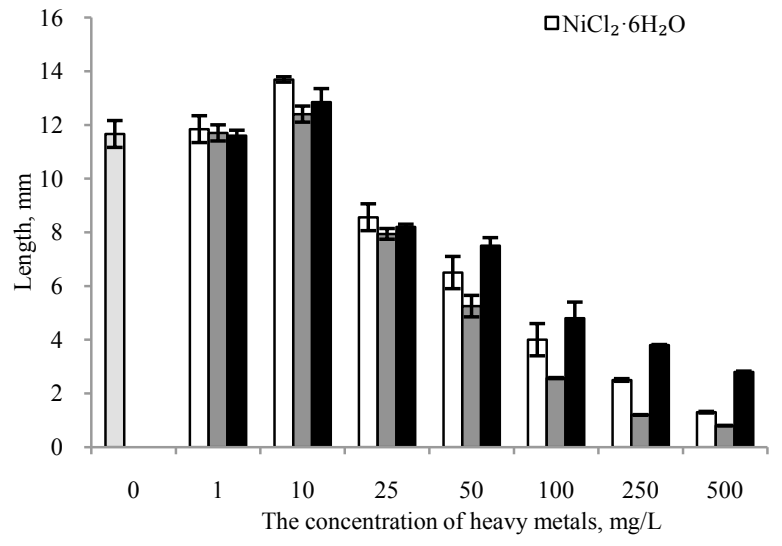

Fig. 5. The effect of heavy metal ions on the length of the cotyledon $(\mathrm{x} \pm \mathrm{SD}, \mathrm{n}=20)$

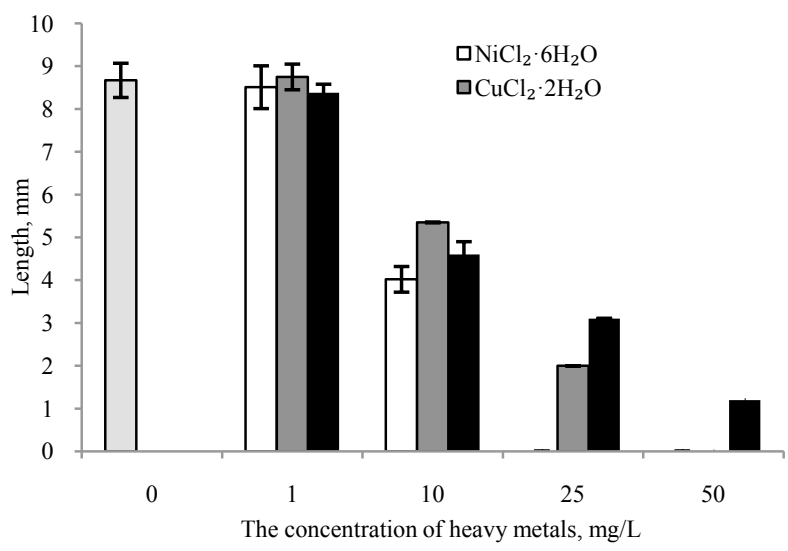

Fig. 6. The effect of heavy metal ions on leaf length $(x \pm S D, n=20)$

\section{Discussion}

Indicators of seed germination (lag time, germination period and germination) in the control indicate their normal ripening and ability to germinate. A change in the germination period showed the effect of nickel and copper ions and their mixtures already at the stage of seed swelling by inhibiting the germination process. A similar effect of heavy metals was discovered by us earlier for other representatives of aquatic plants (Lapirov et al., 2017; Krylova, 2018). In terms of seed germination, copper chloride was more toxic than nickel chloride, and both metals depressed the germination process. It should be noted that $10 \mathrm{mg} / \mathrm{L}$ is the concentration at which adaptation to the action of nickel and activation of protective mechanisms occur. For copper, this concentration is $1 \mathrm{mg} / \mathrm{L}$. A similar effect of copper was also noted by us earlier, and also revealed by other authors (Rozencvet et al., 2003; Krylova, 2013, Krylova et al., 2014). Copper is more toxic than nickel because it is able to displace functional metals from enzymes, interact with biological membranes, and restore molecular oxygen to its active forms (Demidchik et al., 2001). The wave-like nature (sequential increase and decrease) of germination changes with an increase in the concentration of heavy metals reflected the internal rhythm of the development of this species and showed that the germination process is formed from the interaction of the mechanisms of seed emergence from dormancy and potential environmental conditions that meet the conditions for germination (Ivanova, 2006).

During the joint action of two metals on seed germination, a change in the nature of their influence on each other was noted. In the presence of ions of different metals in the solution, their mutual influence during entry into the plant cell occurred already at the first stages of absorption. The concentration of $1 \mathrm{mg} / \mathrm{L}$ caused an independent effect and the joint effect did not differ from the manifestation of the action of each metal separately. Under the action of a concentration of $10 \mathrm{mg} / \mathrm{L}$, germination had an average value of the sum of the toxic effects of each metal sepa- 
rately. Higher concentrations $(25-500 \mathrm{mg} / \mathrm{L})$ were accompanied by antagonism in the action of nickel and copper - metals reduced the toxic effect of each other, as a result of which the germination was higher than with a separate action of each metal. Presumably, this is due to the competition of heavy metals with each other. A significant decrease in germination at high concentrations $(P<0.05)$ was characteristic of both the action of nickel and copper separately, and the influence of their mixture. A number of researchers have shown that the main mechanism of toxicity with increasing concentration of heavy metals is the blocking of important functional groups (Schutzendubel \& Polle, 2002).

Inhibition of seedling growth in the studied species was detected already under the action of $1 \mathrm{mg} / \mathrm{L}$ of both metals and their mixtures. This concentration reduced the length of the main root and increased the number of subordinate roots, which indicated the stimulation of the protective reaction of seedlings by maintaining the total root area and, thus, reducing the influence of the heavy metals. A similar effect of a number of metals on the subordinate roots was also noted in other species (Samantarey et al., 1997; Timofeeva et al., 2016). An increase in the concentration of nickel and copper and their mixture significantly reduced the length of the main root (nickel $\geq 16.5$ times, copper $\geq 6.5$ times, a mixture of nickel and copper $\geq 3.0$ times). Growth inhibition is one of the most important manifestations of heavy metal toxicity in plants, which is associated with their effect on cell division and stretching (Titov et al., 2014). Visually, this was also expressed in partial or complete necrosis of the root system. The tolerance index, which allows one to judge the resistance of the species to heavy metals, showed that at a level above $50 \%$ to the action of nickel, copper and their mixture, it was preserved only in a solution with a concentration of $1 \mathrm{mg} / \mathrm{L}$. With the combined effect of metals on the root system, antagonism was noted in the action of nickel and copper starting from a concentration of $25 \mathrm{mg} / \mathrm{L}$. Under the action of $100 \mathrm{mg} / \mathrm{L}$, the main root was found only in the variant with their mixture, although with a high degree of necrosis.

The hypocotyl and cotyledon are the most resistant parts of seedlings to the action of heavy metals. Under the action of nickel at concentrations of $10-50 \mathrm{mg} / \mathrm{L}$, copper 25 and $50 \mathrm{mg} / \mathrm{L}$ and a mixture of metals at 25 $100 \mathrm{mg} / \mathrm{L}$, the length of the hypocotyl was significantly greater than the control values, i.e. metals at such concentrations stimulated the development of this underground sprout organ. Apparently, the root system of seedlings, acting as a barrier to the penetration of heavy metals, helped to reduce their toxic effect on other organs. However, high concentrations depressed the development of cotyledons and true leaves, which suggests that protective barriers no longer cope with their task (Titov et al., 2003). A change in the intensity of the green colour of the leaves, necrosis, and the hook-like shape of the cotyledons were noted. Moreover, in the case of the development of hypocotyl and cotyledon, copper is more toxic than nickel, while nickel had a greater inhibitory effect on the leaves. We noted earlier a similar effect for other plant species (Krylova et al., 2014).

As a result of the combined effect of nickel and copper on the hypocotyl and cotyledon at concentrations of $1-25 \mathrm{mg} / \mathrm{L}$, an independent effect was noted, as well as on the root system. For leaves, the combined effect did not differ from the isolated action of nickel and copper at $1-10 \mathrm{mg} / \mathrm{L}$. With a concentration of $50 \mathrm{mg} / \mathrm{L}$ for hypocotyl and cotyledon and with $25 \mathrm{mg} / \mathrm{L}$ for leaves, the experiments showed the antagonistic nature of the action of the mixture of nickel and copper. A similar effect of a mixture of metals was revealed by us for another species and a mixture of other salts of nickel and copper (Krylova, 2017). The fact that synergism was shown in the case of the presence of various ions in the solution at low concentrations, and at high concentrations antagonisms has been noted in the literature (Dmitrieva et al., 2002). It is likely that high nickel concentrations decrease the uptake of copper by cells, due to competition for the carrier transporting them through the membrane, and that such changes are caused by oxidative stress due to metal substitution of proteins and enzymes (Mishra \& Kar, 1974; Broadley et al., 2004). The nature of the manifestation of a change in the action of a mixture of metals is determined precisely by metal ions, and not by an acid radical. This was also noted by other authors (Lyanguzova, 1999; Zavershinskij \& Zavershinskaya, 2012; Fiala et al., 2013; Patel et al., 2013).

\section{Conclusion}

Alisma seeds are highly resistant to nickel and copper chlorides and their mixtures. The toxicity limit for seed germination at $1-500 \mathrm{mg} / \mathrm{L}$ was not detected, however, in all variants of the experiment, the germination process was inhibited. In terms of seed germination, a greater toxic effect of copper ions was noted compared to nickel ions. The inhibition coefficient in all variants of the experiment increased. During the joint action of two metals on seed germination, a change in the nature of their influence on each other was noted from independent action at 1 and $10 \mathrm{mg} / \mathrm{L}$, to antagonism at higher concentrations.

The growth and development of seedlings was observed in solutions with concentrations of $1-100 \mathrm{mg} / \mathrm{L}$ of the salts and their studied mixtures. Heavy metals exerted the main inhibitory effect on the length of the main root, the first true leaf, and the number of subordinate roots. We visually observed necrosis of the root system, hypocotyl necrosis and a weakening of the differentiation of the site of transition of the hypocotyl to the cotyledon, a change in the shape of the cotyledon, the colour intensity and turgor of the cotyledon and leaves. The tolerance index, which allows us to judge the resistance of the species to heavy metals, showed that at a level above $50 \%$ to the action of nickel, copper and their mixture, it was preserved only at $1 \mathrm{mg} / \mathrm{L}$. Moreover, in the case of the development of hypocotyl and cotyledon, copper is more toxic than nickel, while nickel had a greater inhibitory effect on the leaves. The experiments showed that under the influence of a mixture of nickel and copper on the growth and development of seedlings, an independent action at low concentrations $(1,10$, and $25 \mathrm{mg} / \mathrm{L}$ ) changed to antagonistic effect at other concentrations, which is probably due to competition in a number of indicators between them.

This work was carried out in the framework of the state budget topic No. AAAAA18-118012690099-2, "Vegetation of water bodies and watercourses in Russia: Structure and dynamics" (head-PhD, associate professor A. G. Lapirov).

\section{References}

Broadley, M. R., Bowen, H. C., Cotterill, H. L., Hammond, J. P., Meacham, M. C., Mead, A., \& White, P. J. (2004). Phylogenetic variation in the shoot mineral concentration of angiosperms. Journal of Experimental Botany, 55, 321-336.

Brygadyrenko, V., \& Ivanyshyn, V. (2015). Changes in the body mass of Megaphyllum kievense (Diplopoda, Julidae) and the granulometric composition of leaf litter subject to different concentrations of copper. Journal of Forest Science, 61(9), 369-376.

Chesnokova, S. M., Savel'ev, O. V., \& Gubskaya, S. V. V. (2016). Ocenka fitotoksichnosti i fermentativnoj aktivnosti pochv gorodskih landshaftov, zagryaznennyh tyazhelymi metallami (na primere goroda Sudogda) [Assessment of phytotoxicity and enzymatic activity of urban landscape soils contaminated with heavy metals (on the example of Sudogda city)]. Advances in Modern Natural Science, 2, 187-192 (in Russian).

Demidchik, V. V., Sokolik, A. I., \& Yurin, V. M. (2001). Toksichnost' izbytka medi i tolerantnost' $\mathrm{k}$ nemu rastenij [Toxicity of excess copper and tolerance of plants to it]. Advances in Modern Biology, 121(5), 511-525 (in Russian).

Devi, S. R., \& Prasad, M. N. V. (2005). Antiokislitel'naya aktivnost' rastenij Brassica juncea, podvergnutyh dejstviyu vysokih koncentracij medi [Antioxidant activity of Brassica juncea plants exposed to high copper concentrations]. Plant Physiology, 52(3), 233-237 (in Russian).

Dmitrieva, A. G., Kozhanova, O. N., \& Dronina, N. L. (2002). Fiziologiya rastitel'nykh organizmov i rol' metallov [Physiology of plant organisms and the role of metals]. Moscow State University, Moscow (in Russian).

Fiala, R., Kenderešova, L., Syshchykov, D. V., Martinka, M., Repka, V., Pavlovkin, J., \& Čiamporova, M. (2013). Comparison of root growth and morphological responses to cadmium and nickel in two maize cultivars. Modem Phytomorphology, 3, 131-137.

Hu, Z. C., Pej, D. L., Lian, F., \& Spi, G. S. (2009). Vliyanie zagryazneniya vody kadmiem na rost rastenij Sagittaria sagittifolia [The effect of cadmium water pollution on the growth of plants of Sagittaria sagittifolia]. Plant Physiology, 56(5), 759-767 (in Russian).

Krylova, E. G. (2013). Prorastanie semyan i razvitie prorostkov chastuhi podorozhnikovoj (Alisma plantago-aquatica L.) v rastvorah solej tyazhelyh metallov [Seed germination and seedling development Alisma plantago-aquatica L. in heavy metal salt solutions]. Water: Chemistry and Ecology, 10, 107111 (in Russian). 
Krylova, E. G. (2017). Nezavisimoe i kombinirovannoe dejstvie solej nikelya i medi na nachal'nye etapy ontogeneza Rumex aquaticus (Polygonaceae) [Independent and combined effect of nickel and copper salts on the initial stages of ontogenesis of Rumex aquaticus (Polygonaceae)]. Plant Rresources, 3, $394-402$ (in Russian).

Krylova, E. G. (2018). The influence of nickel and copper salts on seed germination of native and alien species of Bidens (Asteraceae) from populations of the Upper and Middle Volga. Russian Journal of Biological Invasions, 9(3), 228-231.

Krylova, E. G., Berdnik, K. A., \& Lapirov, A. G. (2014). Vliyanie hloridov nikelya i medi na nachal'nye etapy ontogeneza Bidens cernua (Asteraceae) [Effect of nickel chloride and copper in the initial stages of ontogeny Bidens cernua (Asteraceae)]. Plant Resources, 50(2), 227-235 (in Russian).

Lapirov, A. G., Sigareva, L. E., Krylova, E. G., \& Timofeeva, N. A. (2017). Effect of nickel chloride on seed germination and morphophysiological parameters of seedlings of Alisma plantago-aquatica L. and Sium latifolium L. Inland Water Biology, 10(3), 308-314.

Leurda, I. G. (1969). Mezhdunarodnye pravila opredeleniya kachestva semyan [International rules for determining seed quality]. Kolos, Moscow (in Russian).

Lyanguzova, I. V. (1999). Vliyanie nikelya i medi na prorastanie semyan i formirovanie prorostkov cherniki [Influence of nickel and copper on seed germination and formation of blueberry seedlings]. Plant Physiology, 46(3), 500-502 (in Russian)

Malec, P., Maleva, M. G., Prasad, M. N. V., \& Strzałka, K. (2009). Identification and characterization of Cd-induced peptides in Egeria densa (water weed) Putative role in Cd detoxification. Aquatic Toxicology, 95, 213-221.

Maleva, M. G., Nekrasova, G. F., Borisova, G. G., Chukina, N. V., \& Ushakova, O. S. (2012). Effect of heavy metals on photosynthetic apparatus and antioxidant status of Elodea. Russian Journal of Plant Physiology, 59(2), 190-197.

Maleva, M. G., Nekrasova, G. F., Malec, P., Prasad, M. N. V., \& Strzałka, K. (2009). Ecophysiological tolerance of Elodea canadensis to nickel exposure. Chemosphere, 77, 392-398.

Marenkov, O., Prychepa, M., \& Kovalchuk, J. (2018). The influence of heavy metal ions on the viability and metabolic enzyme activity of the marbled crayfish Procambarus virginalis (Lyko, 2017). International Letters of Natural Sciences, 70, $11-23$.

Mishra, D., \& Kar, M. (1974). Nickel in plant growth and metabolism. Botanical Review, 40(4), 395-452.

Nikolaeva, M. G., Lyanguzova, I. V., \& Pozdova, L. M. (1999). Biologiya semyan [Biology of seeds]. Saint Petersburg State University, Saint Petersburg (in Russian).

Patel, H. V., Parmar, S. R., Chudasama, C. J., \& Mangrola, A. V. (2013). Interactive studies of zinc with cadmium and arsenic on seed germination and anti- oxidant properties of Phaseolus aureus Roxb. International Journal of Plant, Animal and Environmental Sciences, 3(1), 166-174.

Rozencvet, O. A., Murzaeva, S. V., \& Gushchina, I. A. (2003). Akkumulyaciya medi i ee vliyanie na metabolizm belkov, lipidov i fotosinteticheskih pigmentov v list'yah Potamogeton perfoliatus L. [Copper accumulation and its influence on the metabolism of proteins, lipids and photosynthetic pigments in the leaves of Potamogeton perfoliatus L.]. Proceedings of the Samara Scientific Center of the Russian Academy of Sciences, 5(2), 305-311 (in Russian).

Samantarey, S., Rout, G. R., \& Das, P. (1997). Tolerance of rice to nickel in nutrient solution. Biologia Plantarum, 40, 295-298.

Schutzendubel, A., \& Polle, A. (2002). Plant responses to abiotic stresses: Heavy metal-induced oxidative stress and protection by mycorrhization. Journal of Experimental Botany, 53, 1351-1365.

Shipley, B., \& Parent, M. (1991). Germination responses of 64 wetland species in relation to seed size, minimum time to reproduction and seedling relative growth rate. Functional Ecology, 5(1), 111-118.

Timofeeva, N. A., Sigareva, L. E., Krylova, E. G., \& Lapirov, A. G. (2016). Influence of copper and nickel on morphophysiological indicators of seedlings of coastal aquatic plants. Biology Bulletin, 43(3), 244-251.

Titov, A. F., Kaznina, N. M., \& Talanova, V. V. (2014). Tyazhelye metally i rasteniya [Heavy metals and plants]. Karelian Scientific Center of the Russian Academy of Sciences, Petrozavodsk (in Russian).

Titov, A. F., Talanova, V. V., Lajdinen, G. F., \& Kaznina, N. M. (2003). Vliyanie tyazhelyh metallov na rasteniya: Ekologo-fiziologicheskie aspekty [The influence of heavy metals on plants: Ecological and physiological aspects]. Land and aquatic ecosystems of Northern Europe: Management and protection. Pp. 152-157 (in Russian).

Wilkins, D. A. (1978). The measurement of tolerance to edaphic factors by means of root growth. New Phytologist, 80, 623-633.

Zaripova, N. R., \& Stefanovich, K. Y. (2008). Sravnenie vliyaniya ionov kadmiya, medi i nikelya na rasteniya yachmenya na rannih etapah razvitiya [Comparison of the effects of cadmium, copper and nickel ions on barley plants in the early stages of development]. Bulletin of Tver State University, Series Biology and Ecology, 1, 116-122 (in Russian).

Zavershinskij, A. N., \& Zavershinskaya, O. V. (2012). Vliyaniya sovmestnogo prisutstviya ionov nekotoryh tyazhelyh metallov na process formirovaniya prorostkov pshenicy [Influence of the combined presence of some heavy metal ions on the formation of wheat seedlings]. Bulletin of the Tambov University, Series Natural and Technical Sciences, 17(1), 455-456 (in Russian). 